\title{
Reproductive organs of trematode parthenitae during the cold season: an ultrastructural analysis using evidence from rediae of Bunocotyle progenetica (Markowski, 1936) (Digenea, Hemiuroidea)
}

\author{
K.V. Galaktionov', I.M. Podvyaznaya ${ }^{2}$ \\ ${ }^{1}$ Zoological Institute RAS, Universitetskaya emb. 1, St Petersburg 199034, Russia; \\ St Petersburg State University, Universitetskaya emb. 7/9, St Petersburg 199034, Russia. \\ E-mail: Kirill.Galaktionov@zin.ru,kirill.galaktionov@gmail.com \\ ${ }^{2}$ Zoological Institute RAS, Universitetskaya emb. 1, St Petersburg 199034, Russia. \\ E-mail: Irina.Podvyaznaya@zin.ru
}

ABSTRACT: The ultrastructure of reproductive organs of trematode parthenitae during the cold season was investigated for the first time. We used as material the rediae of a monoxenous hemiuroid digenean Bunocotyle progenetica parasitizing intertidal mud snails Peringia ulvae at the White Sea. Infected molluscs were collected in hydrological winter (March) from under the ice at a temperature of near-sediment water of $-1.5-1{ }^{\circ} \mathrm{C}$. The ultrastructural study of the germinal masses and the brood cavity of "winter" rediae revealed substantial differences from their "summer" state described in Podvyaznaya et al. (2019). The mitotic activity in the "winter" germinal masses decreased considerably but did not cease completely. Degenerative processes involving germinal cells and young cercarial embryos were enhanced, while the fully formed cercariae, metacercariae and adult flukes in the redial brood cavity were not affected by degeneration. Degeneration products were absorbed and digested by the cells lining the brood cavity, whose ultrastructural characters indicated an intensification of the digestive function. Feeding on their own degenerating germinal elements during the cold season appears to help the rediae to sustain their own life and that of the advanced stages of the hermaphroditic generation contained in them. In addition, the use of internal food resources presumably makes it possible to decrease the parasitic load on the molluscan host organism during the hardships of the cold season, which promotes the survival of the rediae group. Our data suggest that a traditional view that the functional activity of trematode parthenitae stops completely in winter should be reconsidered.

How to cite this article: Galaktionov K.V., Podvyaznaya I.M. 2019. Reproductive organs of trematode parthenitae during the cold season: an ultrastructural analysis using evidence from rediae of Bunocotyle progenetica (Markowski, 1936) (Digenea, Hemiuroidea) // Invert.Zool. Vol.16. No.4. P.329-341. doi: 10.15298/invertzool.16.4.02

KEY WORDS: trematode parthenitae, reproduction, germinal mass, ultrastructure, parasite transmission, low temperature effect, White Sea.

Paper is dedicated to the memory of A.A. Dobrovolsky.

Статья посвящена памяти А.А. Добровольского. 


\title{
Репродуктивные органы партенит трематод в холодный период - ультраструктурный анализ на примере редий Bunocotyle progenetica (Markowski, 1936) (Digenea, Hemiuroidea)
}

\author{
К.В. Галактионов ${ }^{1}$, И.М. Подвязная² \\ 1 Зоологический институт РАН, Университетская наб. 1, Санкт-Петербург 199034, Рос- \\ сия; Санкт-Петербургскийгосударственныйуниверситет, Университетская наб. 7/9, Санкт- \\ Петербург 199034, Россия. E-mail: Kirill.Galaktionov@zin.ru, kirill.galaktionov@gmail.com \\ 2 Зоологический институт РАН, Университетская наб. 1, Санкт-Петербург 199034, Россия. \\ E-mail: Irina.Podvyaznaya@zin.ru
}

РЕЗЮМЕ. Впервые изучена ультраструктура репродуктивных органов партенит трематод в холодное время года. Материалом послужили редии моноксенной гемиуроидной трематоды Bunocotyle progenetica, паразитирующей в литоральных моллюсках Peringia ulvae Белого моря. Зараженных моллюсков собирали в период гидрологической зимы (март) из-подо льда при температуре пригрунтовой воды $1.5-1{ }^{\circ} \mathrm{C}$. Ультраструктурное исследование герминальных масс и выводковой полости «зимних» редий выявило значимые различия от их «летнего» состояния, описанного нами ранее (Podvyaznaya et al., 2019). Существенно ослабевает, но не прекращается, митотическая активность внутри герминальной массы. Заметно усиливаются дегенеративные процессы, которые затрагивают генеративные клетки и ранние эмбрионы церкарий, но не более продвинутые в своем развитии стадии (сформированные церкарии, метацеркарии и мариты), находящиеся в выводковой полости. Продукты дегенерации поглощаются и перевариваются выстилающими полость клетками, которые демонстрируют ультраструктурные признаки интенсификации пищеварительной функции. Использование в качестве пищевого субстрата собственных дегенерирующих генеративных элементов, по-видимому, помогает редиям поддерживать на необходимом уровне свою жизнедеятельность и жизнедеятельность содержащихся в них особей гермафродитного поколения в холодное время года. Кроме того, питание за счет внутренних ресурсов позволяет значительно снизить паразитарную нагрузку на организм моллюска-хозяина в неблагоприятный холодный период, что способствует выживанию группировки редий. Полученные данные заставляют пересмотреть устоявшиеся взгляды на полное прекращение функциональной активности партенит трематод в зимний период.

Как цитировать эту статью: Galaktionov K.V., Podvyaznaya I.M. 2019. Reproductive organs of trematode parthenitae during the cold season: an ultrastructural analysis using evidence from rediae of Bunocotyle progenetica (Markowski, 1936) (Digenea, Hemiuroidea) // Invert.Zool. Vol.16. No.4. P.329-341. doi: 10.15298/invertzool.16.4.02

КЛЮЧЕВЫЕ СЛОВА: партениты трематод, размножение, герминальная масса, ультраструктура, трансмиссия паразитов, влияние низких температур, Белое море. 


\section{Introduction}

The acquisition of stages parthenogenetically reproducing in molluscs was a key event of digeneans (Trematoda, Digenea) evolution (Galaktionov, Dobrovolskij, 1998, 2003; Cribb et al., 2002; Galaktionov, 2016; Brooks et al., 2019). The "parasitic signal" is strongly amplified during these stages, ensuring further implementation of the complex life cycle along the chain of hosts. The role of reproductive organs in parthenitae is played by the germinal masses, which seem to be a modified ovary of the hermaphroditic ancestor (Dobrovolskij, Ataev, 2003; Galaktionov, Dobrovolskij, 2003; Podvyaznaya, 2007; Podvyaznaya, Galaktionov, 2014). These structures were first found by Cort and his colleagues (see for review Cort et al., 1954), who investigated their structure in parthenitae of various trematode groups (Cort, Oliver, 1943; Cort, 1944; Cort, Ameel, 1944; Ameel et al., 1949; Cort et al., 1949, 1950). Detailed studies of germinal masses and their functioning were conducted at the Department of Invertebrate Zoology of the Leningrad State University starting from the late 1960ies under the supervision of A.A. Dobrovolskij (Dobrovolskij, Raichel, 1973; Gerasev, Dobrovolskij, 1977; Dobrovolskij, Mukhamedov, 1979; Mukhamedov, 1979; Dobrovolskij et al., 1983; Galaktionov, Dobrovolskij, 1985) and were later continued by his disciples (Ataev, Dobrovolskij, 1990; Kofiadi, 1995; Ataev et al., 1997, 2001, 2006, 2007, 2013, 2016; Isakova, 2011; Ataev, Tokmakova, 2015). These studies, carried out at the light microscopic level, indicated that the organisation of germinal masses is generally similar in parthenitae of different trematode taxa (Dobrovolskij et al., 2000; Dobrovolskij, Ataev, 2003; Galaktionov, Dobrovolskij, 2003; Isakova, 2011). According to the results of this research, germinal mass is a compact structure, which is either associated with the body wall of the parthenita (attached to it or inbuilt into it) or floats freely in the brood cavity. It consists of germinal cells, stem (undifferentiated) cells and supporting cells as well as early embryos of the next generation (partheni- tae or cercariae) until the formation of the primitive epithelium (that is, until the stage of germinal balls). Supporting cells form numerous branching outgrowths enveloping the germinal elements of the germinal mass and ensuring its structural integrity. In addition, they also seem to be "conducting elements" along which nutrients are transported to other components of the germinal mass. Stem cells divide and differentiate either into germinal or into supporting cells. Germinal cells are only capable of cleavage, and give rise to individuals of the next generation. As embryos mature and grow, they rupture the enveloping outgrowths of supporting cells and get out into the brood cavity of the parthenita, where they mature further. Once their development is completed, fully formed cercariae or young parthenitae leave the mother organism through a birth pore or local ruptures of the body wall.

Recently, we conducted the first ultrastructural studies of germinal masses in parthenitae of different morphotypes (sporocysts with modular organisation, rediae of different types) in species from phylogenetically distant trematode families (Podvyaznaya, 2007; Podvyaznaya, Galaktionov, 2014, 2018; Podvyaznaya et al., 2019). These investigations have confirmed the conclusion about a uniform cellular composition of the germinal masses across different digenean groups. At the same time, electron microscopy has shown that the fine structure of germinal masses is considerably diverse, the differences being mostly associated with the structural variation of their supporting tissue as well as the number and age of embryos inside them. Our studies have also demonstrated similarities in ultrastructure between undifferentiated and germinal cells of the germinal masses in sporocysts and rediae of different trematodes. Germinal cells were found to contain organelles typical of animal oocytes such as germ granules (or nuage) and annulate lamellae, which is an additional evidence that they belong to the germline.

With a single exception, which will be discussed below, all studies devoted to the analysis of structure and function of germinal masses 
were made in the period of their functional activity, that is, during the warm season. This is the time when groups of parthenitae actively produce cercariae and the latter emerge from the molluscan host (see for review Ginetsinskaya, 1968; Smyth, Halton, 1983; Dobrovolskij et al., 1983; Galaktionov, Dobrovolskij, 1998, 2003). Numerous studies of seasonal dynamics of cercarial emergence have shown that it stops during the cold season (e.g., Werding, 1969; Robson, Williams, 1970; Lauckner, 1980; Hughes, Answer, 1982; Lemly, Esch, 1984; Schmidt, Fried, 1997; Field, Irwin, 1999; Marcogliese, 2001; Peterson, 2007; Thieltges, Rick, 2006; Prokofiev, 2006). The composition of the groups of parthenitae in the molluscan host also changes in winter (e.g., Køie, 1975; Machkevsky, 1982; Rusanov, Galaktionov, 1984; Ataev, 1991; Taskinen et al., 1994; Abdul-Salam et al., 1997; Sendersky et al., 2002; Kube et al., 2002; Galaktionov et al., 2006; Korniychuk, 2008; Levakin, 2008; Averbuj, Cremonte, 2010; Fermer et al., 2010; Prinz et al., 2010; Nikolaev, 2012; Ataev, Tokmakova, 2015). If there are only two generations of parthenitae (mother and daughter sporocysts) in the group, the development of embryos in daughter sporocysts is suspended, while mature cercariae, that have not emerged before the drop of temperature, may die and resorb during the winter (our unpublished data). In self-sustaining groups of rediae/daughter sporocysts (the so-called microhemipopulations or self-sustaining infrapopulations - see Galaktionov et al., 2014, 2015), the character of reproduction may change with the onset of the cold spell: instead of producing cercariae, rediae start to produce rediae of the next generation (Chowaniec, 1961; Bednarz, 1962; Kendall, 1965; Dinnic, Dinnic, 1964; Machkevskiy, 1982; Rusanov, Galaktionov, 1984; Korniychuk, 2008). For groups of rediae of Himasthla spp. parasitising molluscs Littorina spp. at the White Sea, Nikolaev (2012) found that a drop of temperature in autumn resulted in the death of the majority of the mature individuals that have actively produced cercariae during the summer. They are substituted by young individuals from the pool of young parthenitae present in the group, whose development has previously been retarded. In experiments with molluscs Melanopsis praemorsa (Linnaeus, 1758) infected with Philophthalmus rhionica Tikhomirov, 1980, Ataev (1991) demonstrated that the rate of embryogenesis of both cercariae and rediae decreased at low water temperature $\left(0-2{ }^{\circ} \mathrm{C}\right)$.

All these materials indicate that the reproduction of parthenitae and the development of their progeny is suspended during the cold season. The functional activity of reproductive organs, the germinal masses, should decrease correspondingly, which was indeed found in a comparative study of "summer" and "winter" germinal masses in daughter sporocysts of Xiphidiocercaria sp. VII Odening, 1962, carried out under the supervision of A.A. Dobrovolskij (Mukhamedov, 1979, 1981). In winter the germinal masses of sporocysts of this species are considerably smaller than in summer, there are fewer cercarial embryos forming in them, and these embryos are smaller in size. No dividing cells were found in the winter germinal masses, all the cells were in the interphase. It would seem that in winter the development of the parthenitae is arrested, and they enter the state of hypobiosis (developmental arrest), leaving it only when the water warms up in spring.

Since no studies of fine structure of reproductive organs of parthenitae in the winter period have ever been carried out, we decided to perform such a research. The chosen object of our study was Bunocotyle progenetica (Markowski, 1936) Chabaud et Buttner, 1959. This parasite of intertidal molluscs Peringia ulvae (Pennant, 1777) (syn. Hydrobia ulvae (Pennant, 1777)) and Ecrobia ventrosa (Montagu, 1803) (syn. Hydrobia ventrosa (Montagu, 1803)) is common at the White Sea. This species has a monoxenous life cycle, with all the phases being confined to one and the same molluscan host. The miracidium, after hatching in the gut of the mollusc that has swallowed an egg of the parasite, penetrates the gut wall and, already in the hemocoel, develops into a large, motile mother sporocyst giving birth to rediae. In the rediae, individuals of the hermaphroditic generation are formed, from early embryos to 
adult egg-producing flukes. The eggs are released into the environment after the death of the molluscan host (Levakin, 2008). The germinal mass of rediae of B. progenetica is attached to the body wall. Its ultrastructural organisation in the period of active functioning (in summer) was described in our earlier study (Podvyaznaya et al., 2019). We have shown that the germinal mass, the brood cavity of the redia and its birth canal opening with a birth pore on the outer surface of the parthenita, are elements of a welldeveloped integrated reproductive apparatus, in which the germinal mass is a functional equivalent of the gonad and all the other structures mentioned above play the role of efferent ducts. In the Results section below the attention is mainly focussed on the differences in the organisation of reproductive structures in the "winter" and the "summer" rediae.

\section{Materials and methods}

Mud snails $P$. ulvae infected with $B$. progenetica were collected in March 2017 in Sukhaya Salma creek of the Chupa Inlet (the Kandalaksha Bay of the White Sea). The sea was covered with ice at that time, with the water temperature in the intertidal being $-1.5--1{ }^{\circ} \mathrm{C}$ (Babkov, 1998). The molluscs together with the sediment were sampled from under the ice and transported to the laboratory of the White Sea Biological Station of the Zoological Institute of the Russian Academy of Sciences. There the mud snails were cleared from the sediment with seawater with a temperature of about $0{ }^{\circ} \mathrm{C}$ and dissected under a stereomicroscope. Rediae obtained from infected $B$. progenetica molluscs were immediately fixed and treated for electron microscopic studies following a technique described in Podvyaznaya et al. (2019). Thin and semithin sections of rediae were made with the help of a Leica EM UC6rt ultramicrotome. Thin sections were stained with an aqueous solution of uranyl acetate and lead citrate after Reynolds and examined with the help of a Morgagni 268 transmission electron microscope at a voltage of 80 $\mathrm{kV}$. Semithin sections were stained with tolui- dine blue and viewed under Leica DMLS microscope. For TEM studies of the germinal mass and the brood cavity we selected 1) individuals whose development corresponded to young "summer" rediae studied earlier, that is, whose brood cavity mostly contained germinal balls ( 3 ind.) as well as 2) mature rediae containing fully formed cercariae, metacercariae and adult flukes (2 ind.).

\section{Results}

General structural plan of the germinal mass in all the studied "winter" rediae of $B$. progenetica corresponded to that described before in the "summer" rediae (Podvyaznaya et al., 2019). In both cases the germinal mass contained a few undifferentiated cells, germinal cells at various stages of maturation and supporting cells, which formed the interstitial tissue of the organ and its sheath and lined the internal lacunae (Fig. 1AD). Germinal masses of the "summer" and the "winter" rediae contained numerous early embryos up to the stage of young germinal balls (Fig. 1A-C). Visible seasonal differences in the structure of the germinal masses mainly concerned physiological state of their elements. For instance, we found mitoses - primarily in separate cells (undifferentiated and mature germinal cells) and sometimes in blastomeres of embryos - in all the studied "winter" individuals (Fig. 2A-C). However, they were found on sections much less frequently (from 3 to 5 per germinal mass in total) than in the "summer" rediae (from 2 to 7 per section). At the same time, in the "winter" parthenitae, as compared with the "summer" ones, the number of degenerating cells and pyknotic bodies in the germinal mass increased considerably, with some parts of the organ being almost completely filled with them (Fig. 1B). Besides separate degenerating cells, germinal masses of all the "winter" rediae examined contained many degenerating embryos, which were especially numerous in mature individuals (Fig. 1C). In young "summer" rediae degenerating embryos in the germinal mass were only sporadically found. 


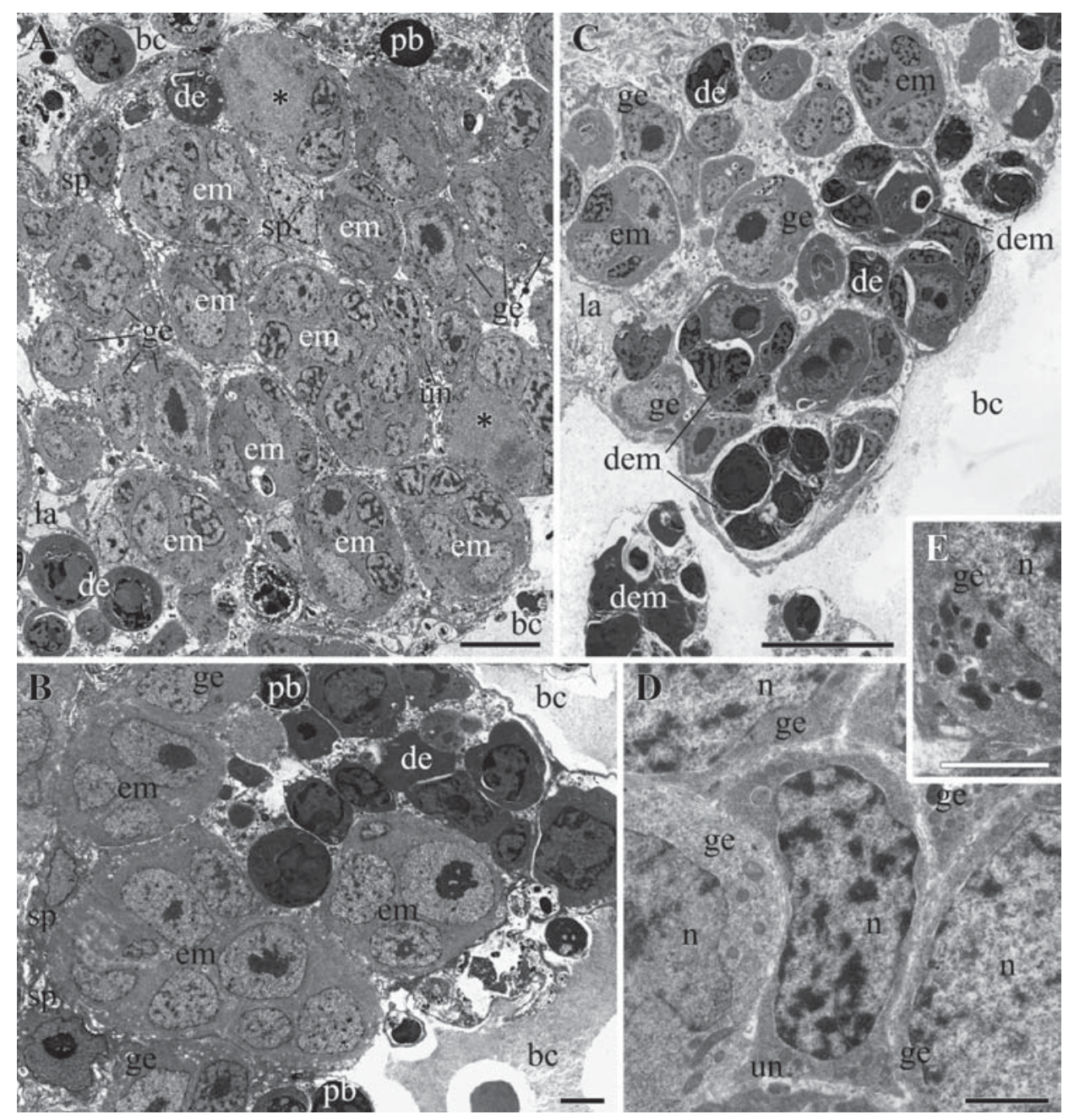

Fig. 1. General structure of the germinal masses in "summer" and "winter" rediae of Bunocotyle progenetica. A - TEM section of the germinal mass of the "summer" redia; B - TEM section of the germinal mass of the "winter" redia, containing germinal balls; note numerous degenerating cellular elements; C - TEM section of the germinal mass of the "winter" mature redia; note degenerating cells and embryos inside the organ; D - undifferentiated and germinal cells in the germinal mass of the "winter" mature redia; E autolysosome-like vesicles in the germinal cell of the "winter" mature redia.

Abbreviations: asterisk $\left(^{*}\right)$ - mitotic cell; bc — brood cavity; de — degenerating cells; dem — degenerating embryos; em - embryos; ge - germinal cells; la - internal lacunae of the germinal mass; $\mathrm{n}$ - nucleus; $\mathrm{pb}$ - pyknotic body; $\mathrm{sp}-$ supporting cells; un - undifferentiated cell. Scale bars: A $-5 \mu \mathrm{m}$; B $-2 \mu \mathrm{m} ; \mathrm{C}-8 \mu \mathrm{m} ; \mathrm{D}, \mathrm{E}-1 \mu \mathrm{m}$.

Рис. 1. Общее строение герминальных масс у «летних» и «зимних редий Bunocotyle progenetica. A TEM-срез герминальной массы «летней» редии; В - TEM-срез герминальной массы «зимней» редии, содержащей зародышевые шары; отметьте многочисленные дегенерирующие клеточные элементы; С - TЕМ-срез герминальной массы «зимней» зрелой редии; отметьте дегенерирующие клетки и эмбрионы внутри органа; D - недифференцированные и генеративные клетки герминальной массы «зимней» зрелой редии; Е - везикулы похожие на аутолизосомы в генеративной клетке «зимней» зрелой редии.

Обозначения: астериск $\left({ }^{*}\right)$ - митотические клетки; bc - выводковая полость; de - дегенерирующие клетки; dem - дегенерирующие эмбрионы; em - эмбрионы; ge - генеративные клетки; la - внутренние лакуны герминальной массы; $\mathrm{n}$ - ядро клетки; $\mathrm{pb}$ - пикнотическое тело; $\mathrm{sp}$ - поддерживающие клетки; un недифференцированные клетки. Масштабные линейки: А -5 мкм; В - 2 мкм; С - 8 мкм; D, E - 1 мкм. 
Fig. 2. TEM images of mitotic cells in the germinal masses of "winter" rediae of Bunocotyle progenetica. A - mitotic division (asterisk) at the periphery of the germinal mass in the "winter" redia, containing germinal balls; B - mitotic division (asterisk) at the periphery of the germinal mass in the "winter" mature redia; $\mathrm{C}-$ mitotic division (asterisk) at the base of the germinal mass in the "winter" mature redia; note the basal laminae (arrowheads) separating the germinal mass from the redial body wall.

Abbreviations: bc — brood cavity; bw — redial body wall; dem — degenerating embryos; ge — germinal cells; gm germinal mass; $\mathrm{n}$ - nucleus; $\mathrm{pb}$ - pyknotic body; $\mathrm{sp}$ supporting cell. Scale bars: A, B $-2 \mu \mathrm{m} ; \mathrm{C}-1 \mu \mathrm{m}$.

Рис. 2. ТЕМ-изображения митотически делящихся клеток в герминальной массе «зимних» редий Bunocotyle progenetica. A - митотическое деление (астериск) в периферической части герминальной массы редии, содержащей зародышевые шары; В - митотическое деление (астериск) в периферической части герминальной массы зрелой редии; С - митотическое деление (астериск) в базальной части герминальной массы зрелой редии; отметьте базальную пластинку (стрелки), отделяющую герминальную массу от стенки тела редии.

Обозначения: bc - выводковая полость; bw - стенка тела редии; dem - дегенерирующие эмбрионы; ge генеративные клетки; gm - герминальная масса; $\mathrm{n}$ клеточное ядро; $\mathrm{pb}$ - пикнотическое тело; $\mathrm{sp}$ - поддерживающая клетка. Масштабные линейки: A, B - 2 мкм; С -1 мкм.

In mature "winter" rediae ultrastructural changes were also noted in the germinal cells unaffected by pyknosis (Fig. 1E). They often contained accumulations of vesicles which looked like autophagosomes and autolysosomes.

Evident seasonal changes were also observed in the contents of the brood cavity and in the structure of its cellular lining (Fig. 3A-E). As compared with young "summer" rediae, the brood cavity of young "winter" ones contained much more cellular debris and many more degenerating early embryos (Fig. 3A, B), including those disintegrating into separate cells. $\mathrm{Cu}$ riously, fully formed cercariae, metacercariae and adults in the brood cavity of mature "winter" rediae did not show any salient features of degeneration. On the contrary, the adults were
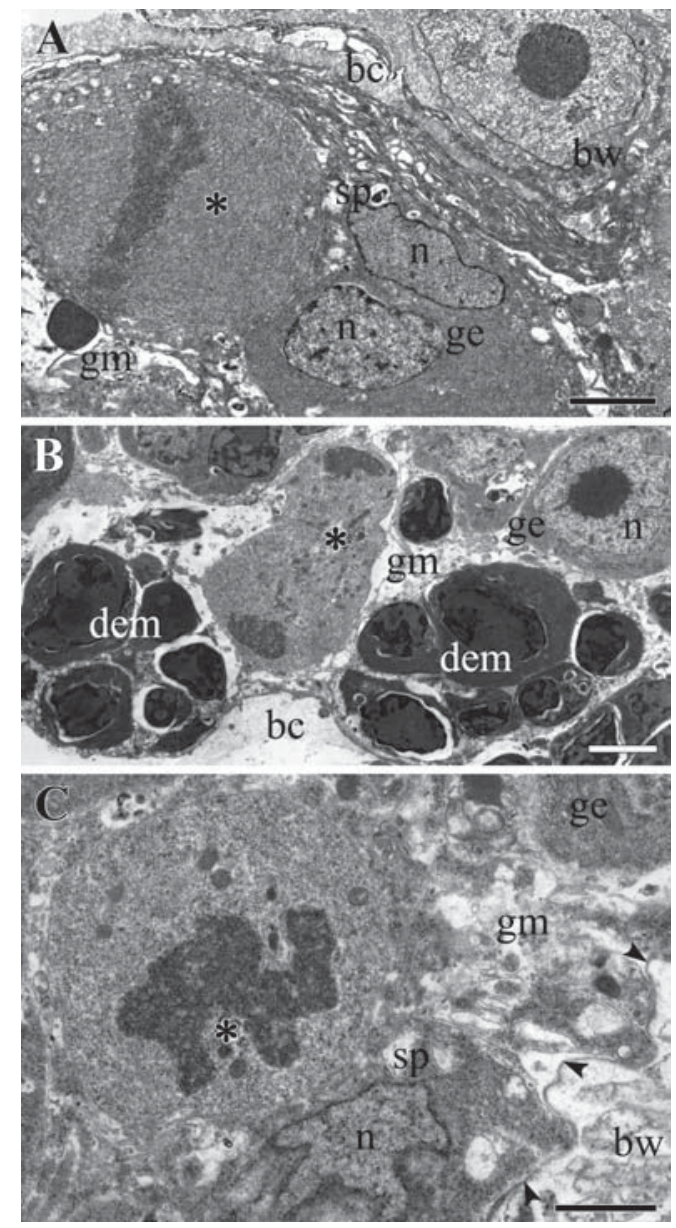

even active and discharged spermatozoa, which were regularly seen in the brood cavity (Fig. $3 \mathrm{E})$, often near the germinal mass.

Perikarya of the cells lining the brood cavity in "winter" rediae (Fig. 3D, E) had a much greater volume than in the "summer" individuals (Fig. 3C) and were filled with numerous residual bodies of different outlook and size, vesicular structures resembling lysosomes and endosomes as well as degenerating cells and pyknotic bodies absorbed from the brood cavity (Fig. 3D, E).

\section{Discussion}

Our data indicate that the organisation of reproductive structures in the rediae of B. pro- 

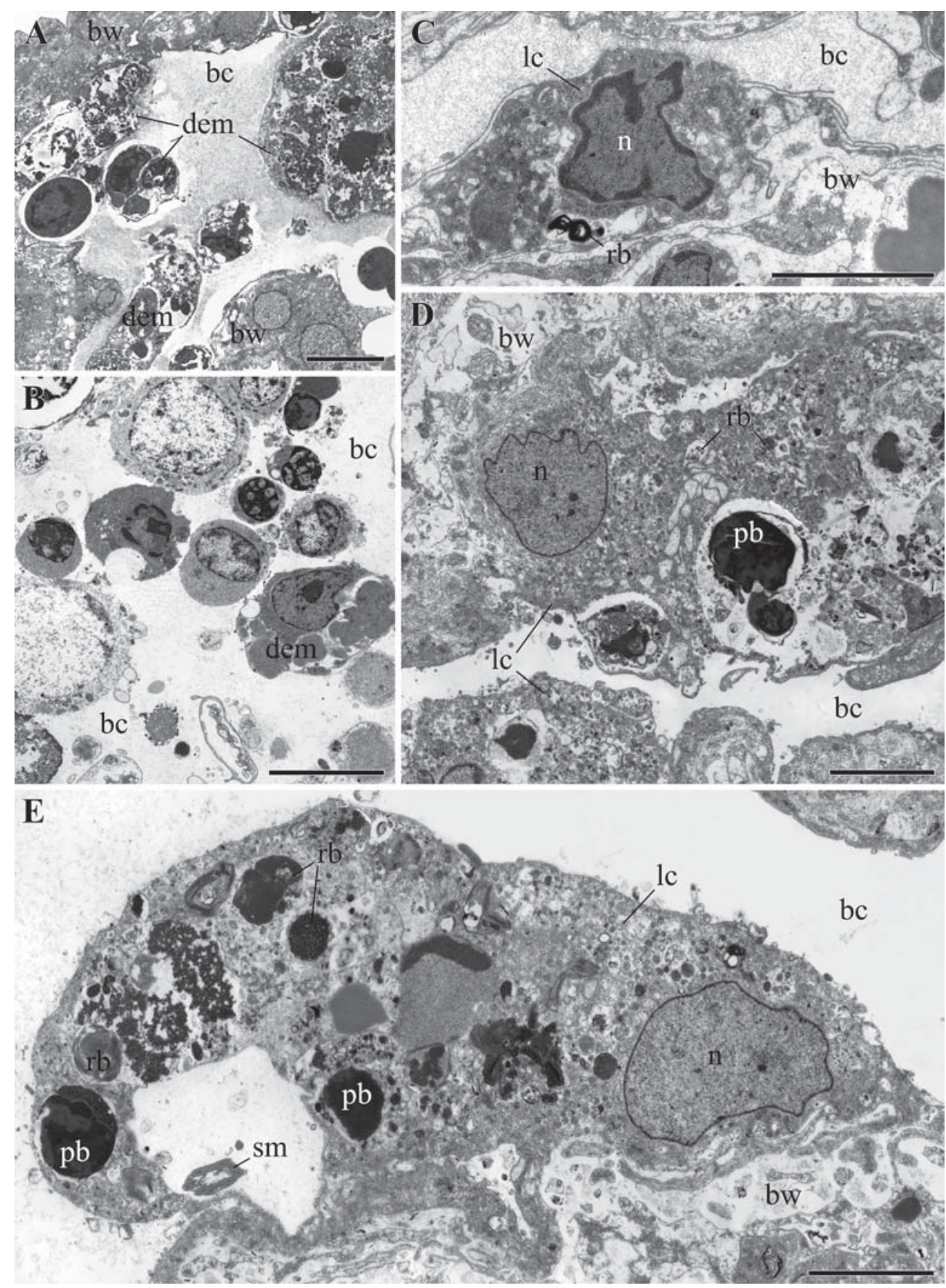

Fig. 3. Brood cavity and its lining in "winter" and "summer" rediae of Bunocotyle progenetica. A degenerating early embryos in the brood cavity of "winter" redia; B - cellular debris in the brood cavity of "winter" redia; C - the cell lining the brood cavity in "summer" young redia; D, E - the cells lining the brood cavity in "winter" mature rediae.

Abbreviations: bc — brood cavity; bw — redial body wall; dem — degenerating embryos; lc — lining cells; $\mathrm{n}$ — nucleus; $\mathrm{pb}$ - pyknotic body; $\mathrm{rb}$ - residual body; sm - sperm cell. Scale bars: A, B $-5 \mu \mathrm{m} ; \mathrm{C}-2 \mu \mathrm{m} ; \mathrm{D}, \mathrm{E}-3 \mu \mathrm{m}$. 
genetica in the cold season undergoes significant changes as compared with their summer state. Mitotic activity in the germinal masses declines considerably, though it does not cease completely. This means that the reproductive organ continues to function but with a lower intensity. At the same time, there is a noticeable surge of degenerative processes, which now involve not only germinal cells as in "summer" rediae (see Podvyaznaya et al., 2019) but also the early embryos, both inside the germinal mass and in the brood cavity. As a result, the number of viable young embryos in "winter" individuals does not increase; it may even decrease as compared with "summer" rediae at the same developmental stage. Products of degeneration that pass from the germinal mass into the brood cavity as well as those that are formed in the cavity itself are absorbed and digested by its lining cells. In "winter" rediae, ultrastructural characters of these cells indicate an intensified digestive function: the volume of their cytoplasm increases dramatically and so does the number of various endosome- and lysosomelike vesicles, residual bodies and absorbed degenerating cells, including pyknotic bodies.

It seems probable that an active utilization of considerable amounts of products of degeneration of embryos and germinal cells in the cold season has, primarily, a trophic function. The use of their own degenerating germinal elements as a food substrate seems to help rediae to sustain at the necessary level their own life activity and that of fully formed cercariae, metacercariae and adults contained in them. The above mentioned stages of the hermaphroditic generation, found in "winter" rediae, have formed in them before the onset of the cold season and are unaffected by the degeneration. It is reasonable to suppose that they should be provided with nutrients in the first place: further implementation of the life cycle depends on these individuals, and all the systems of rediae are designed to ensure their normal development and reproduction in the adult phase. The number of adults in mature rediae in infected $P$. ulvae does not exceed 10-15 (our data), and when they mature, embryos that lagged behind in their development are resorbed anyway, and so are even fully formed cercariae (Levakin, 2008).

An enhancement of degenerative processes in winter and, thus, an increased role of internal resources in the feeding of rediae and advanced stages of hermaphroditic generation, also makes it possible to considerably decrease the parasitic load on the host organism during the adverse cold season. This idea is supported by experimental data of Levakin $(2005,2008)$ on the survival of "winter" molluscs $P$. ulvae (collected in March from under ice at the White Sea). The author showed that the infection with $B$. progenetica did not influence the mortality rate of molluscs at low temperatures (below zero ${ }^{\circ} \mathrm{C}$ ) and suggested that this was associated with a seasonal decrease of the parasitic load on the host organism (Levakin, 2005, 2008).

There is nothing unusual in the degeneration of germinal elements of parthenitae. In some degree it is observed in almost all sporocysts and rediae whose development has been studied (Dobrovolskij et al., 1983; Galaktionov, Dobrovolskij, 2003). Furthermore, degeneration of some cells resulting in the formation of pyknotic bodies is observed during the development of any trematode embryo. The products of the degeneration are probably used as food both by parthenitae themselves and by the embryos. Kofiadi (1995) observed a more active degeneration of early cercarial embryos in winter and at certain stages of ontogenesis in daughter sporocysts of Hemiuridae gen. sp. parasitizing the

Рис. 3. Выводковая полость и ее выстилка у «зимних» и «летних» редий Bunocotyle progenetica. A дегенерирующие ранние эмбрионы в выводковой полости «зимней» редии; В - клеточный дебрис в выводковой полости «зимней» редии; С — клетка выстилки выводковой полости молодой «летней» редии; D, Е - клетки, выстилающие выводковую полость «зимней» зрелой редии.

Обозначения: bc - выводковая полость; bw - стенка тела редии; dem - дегенерирующие эмбрионы; lc выстилающие клетки; $\mathrm{n}$ - клеточное ядро; pb - пикнотическое тело; rb - остаточное тело; sm - спермий. Масштабные линейки: А, В - 5 мкм; C - 2 мкм; D, E - 3 мкм. 
caenogastropode Nucella lima (Gmelin, 1791). $\mathrm{He}$ considered it as an adaptation to surviving adverse environmental conditions as well as an additional adaptation to prolongation of the individual life of the daughter parthenitae.

Our data do not agree quite well with those of Mukhamedov (1979), who did not found any mitoses in the winter germinal masses of Xiphidiocercaria sp. VII. At the same time, this author noted that there were dividing cells in cercarial embryos, though their number was infinitesimal as compared to the summer state (dividing cells made up $0.15 \%$ of the total number of cells in the embryos)(Mukhamedov, 1979). To note, daughter sporocysts of Xiphidiocercaria sp. VII can produce only cercariae, which do not leave the parthenitae in winter, and their transmission to the second intermediate host is impossible. There are no such limitations in the transmission of $B$. progenetica, with its monoxenous life cycle. Therefore, a certain continuation of the development in winter makes sense, as far as physiological mechanisms allow. That such a continuation indeed takes place is indicated by our data presented here as well as by the results of detailed studies of seasonal dynamics of the composition of groups of parthenitae of $B$. progenetica (Levakin, 2008). Comparison of their composition in late autumn (November), winter (March) and early spring (May) showed that some growth and development of mother sporocysts and adults in mature groups of rediae occurs in winter, too (Levakin, 2008).

In conclusion, our data on the ultrastructure of reproductive organs in the rediae of $B$. progenetica make one reconsider the traditional view that the functional activity of parthenitae stops completely in the winter period. At least in some species it may be sustained, albeit in a strongly curtailed version, during the cold season, too.

\section{Acknowledgements}

Collection and primary processing of the material were carried out within the framework of the Russian Foundation for Basic Research grant no. 16-04-00753. Electron microscopic data were mostly obtained and analysed within the framework of the Russian Science Founda- tion grant No. 18-14-00170. Transmission electron microscopy was performed at the "Taxon" Research Resource Centre (Zoological Institute, Russian Academy of Sciences) (http:// www.ckp-rf.ru/ckp/3038/?sphrase_id= 8879024).

\section{References}

Abdul-Salam J., Sreelatha B.S., Al-Kandari W. 1997. Temporal variations in the infection of a population of Clypeomorus bifasciata (Gastropoda: Prosobranchia) by a digenean microphallid larva in Kuwait Bay // J. Helminthol. Vol.71. P.1-7.

Ameel D.J., Cort W.W., Van der Woude A. 1949. Germinal development in the mother sporocyst and rediae of Halipegus eccentricus Thomas // J. Parasitol. Vol.35. P.569-578.

Ataev G.L. 1991. [Effect of temperature on the development and biology of rediae and cercariae of Philophthalmus rhionica (Trematoda)] // Parazitologiya. Vol.35. No.4. P.349-359 [in Russian with English summary].

Ataev G.L., Dobrovolskij A.A. 1990. [Development of microhemipopulation of parthenitae of the trematode Philophthalmus rhionica] // Parazitologiya. Vol.24. No.6. P.499-508 [in Russian with English summary]. Ataev G.L., Tokmakova A.S. 2015. [Seasonal changes in the biology of Leucochloridium paradoxum sporocysts (Trematoda: Leucochloridiidae)] // Parazitologiya. Vol.49. No.3. P.200-207 [in Russian with English summary].

Ataev G.L., Bazhenova D.R., Tokmakova A.S. 2016. [Reproduction of Schistosoma mansoni mother sporocysts] // Parazitologiya. Vol.50. No.2. P.114-120 [in Russian with English summary].

Ataev G.L., Dobrovolskij A.A., Tokmakova A.S. 2013. [Reproduction of Leucochloridium paradoxum sporocysts (Trematoda: Leucochloridiidae)] // Parazitologiya. Vol.47. No.2. P.178-182 [in Russian with English summary].

Ataev G.L., Isakova N.P., Dobrovolskij A.A. 2006. [Development of mother sporocysts of Echinostoma caproni (Trematoda: Echinostomatidae)] // Parazitologiya. Vol.40. No.1. P.47-56 [in Russian with English summary].

Ataev G.L., Isakova N.P., Dobrovolskij A.A. 2007. [Reproduction of the trematode Echinostoma caproni parthenitae (Digenea: Echinostomatidae)] // Parazitologiya. Vol.41. No.6. P.512-525 [in Russian with English summary].

Ataev G.L., Avanessian A.V., Loker E.C., Dobrovolskij A.A. 2001. The organization of germinal material and dynamics of mother sporocyst reproduction in the genus Echinostoma (Trematoda: Echinostomatidae) // Parazitologiya. Vol.35. P.307-319 [in Russian with English summary]. 
Ataev G.L., Dobrovolskij A.A., Fournier A., Jourdane J. 1997. Migration and development of mother sporocyst of Echinostoma caproni (Digenea: Echinostomatidae) // J. Parasitol. Vol.83. P.444-453.

Averbuj A., Cremonte F. 2010. Parasitic castration of Buccinanops cochlidium (Gastropoda: Nassariidae) caused by a lepocreadiid digenean in San José Gulf, Argentina // J. Helminthol. Vol.84. P.381-389.

Babkov A.I. 1998. [Hydrology of the White Sea.] SaintPetersburg: Zool. Inst. RAN. 93 p. [In Russian]

Bednarz S. 1962. The development cycle of germ cells in Fasciola hepatica L. 1758 (Trematodes, Digenea) // Zool. Polon. Vol.12. P.439-466.

Brooks D.R., Hoberg E.P., Boeger W.A. 2019. The Stockholm Paradigm. Climatic change and emerging diseases. Chicago, London: The University of Chicago Press. 433 p.

Chowaniec W. 1961. Influence of environment and development of liver fluke and the problem of superinvasion and reinvasion in the intermediate host // Acta Parasitol. Polon. Vol.9. P.463-480.

Cort W.W. 1944. The germ cell cycle in the digenetic trematodes // Quart. Rev. Biol. Vol.19. P.275-284.

Cort W.W., Ameel D.J.1944. Further studies on the development of the sporocyst stages of plagiorchiid trematodes // J. Parasitol. Vol.30. P.37-56.

Cort W.W., Oliver L. 1943. The development of the larval stages of Plagiorchis muris Tanabe, 1922, in the first intermediate host // J. Parasitol. Vol.29. P.81-99.

Cort W.W., Ameel D.J., Van der Woude A. 1949. Germinal masses in redia embryos of an echinostome and a psilostome // J. Parasitol. Vol.35. P.579-582.

Cort W.W., Ameel D.J., Van der Woude A. 1950. Germinal material in the rediae of Clinostomum marginatum (Rud.) // J. Parasitol. Vol.36. P.157-163.

Cort W.W., Ameel D.J., Van der Woude A. 1954. Germinal development in the sporocysts and rediae of the digenetic trematodes // Exp. Parasitol. Vol.3. P.185255.

Cribb T.H., Chisholma L.A., Bray R.A. 2002. Diversity in the Monogenea and Digenea: does lifestyle matter? // Int. J. Parasitol. Vol.32. P.321-328.

Dinnic J.A., Dinnic N.N. 1964. The influence of temperature on the succession of rediae and cercariae generations of Fasciola gigantica in a snail host // Parasitology. Vol.54. No.1. P.59-65.

Dobrovolskij A.A., Ataev G.L. 2003. The nature of reproduction of Digenea rediae and sporocysts // C. Combes (ed.). Hommage à Louis Euzet - Taxonomy, Ecology, and Evolution of Metazoan Parasites. Perpignan, France: Presses Universitaires de Perpignan. P.249-272.

Dobrovolskij A.A., Mukhamedov G.K. 1979. [Some features of reproduction in the mother sporocysts of Xiphidiocercaria sp. VII Odening (Trematoda, Plagiorchiata)] // Yu. Polianskiy (ed.). Ecologich. Experiment. Parazitol. Leningad Univ. Press. Vol.2. P.4247 [in Russian].

Dobrovolskij A.A., Reichel A.C. 1973. [Life cycle of Haplometra cylindracea Zeder, 1800 (Trematoda,
Plagiorchiidae)] // Vestnik Leningr. Univer. Vol.3. P.5-13 [in Russian with English summary].

Dobrovolskij A.A., Galaktionov K.V., Ataev G.L. 2000. [Peculiarities of the generative material organization and proliferation dynamics of trematode mother sporocysts] // Parazitologiya. Vol.34. No.1. P.14-24 [in Russian with English summary].

Dobrovolskij A.A., Galaktionov K.V., Mukhamedov G.K., Sinha B.K., Tikhomirov I.A. 1983. [Parthenogenetic generations of trematodes] // Tr. Leningr. Obshestva Estestvoispytatelei Vol.82. P.1-108 [in Russian].

Fermer J., Culloty S.C., Kelly T.C., O’Riordan R.M. 2010. Temporal variation of Meiogymnophallus minutus infections in the first and second intermediate host // J. Helminthol. Vol.84. P.362-368.

Field L.C., Irwin S.W.B. 1999. Digenean larvae in Hydrobia ulvae from Belfast Lough (Northern Ireland) and the Ythan Estuary (north-east Scotland) // J. Mar. Biol. Assoc. U. K. Vol.79. No.3. P.431-435.

Galaktionov K.V. 2016. [Evolution and biological radiation of trematodes: A synopsis of ideas and opinions] // K.V. Galaktionov (ed.). Koevolutsia parazitov i khoziaev. Saint-Petersburg: Zool. Inst. RAN (Tr. Zool. Ins. RAN. T.320. Prilozhenie 4). P. 74-126 [in Russian with English summary].

Galaktionov K.V., Dobrovolskij A.A. 1985. [Development and reproduction of the mother generation of parthenitae of trematodes of the genus Microphallus (Plagiorchiida, Microphallidae)] // Zool. Zhurn. Vol.64. P.1468-1475 [in Russian with English summary].

Galaktionov K.V., Dobrovolskij A.A. 1998. [Origin and evolution of trematode life cycles]. Nauka. St. Petersburg, Russia. 404 p. [In Russian with English summary]

Galaktionov K.V., Dobrovolskij A.A. 2003. The biology and evolution of trematodes: an essay on the biology, morphology, life cycles, transmission, and evolution of digenetic trematodes. Boston, Dordrecht, London: Kluwer Academic Publ. 592 p.

Galaktionov K.V., Dobrovolskij A.A., Podvyaznaya I.M. 2014. [Evolution of morpho-functional organization of trematode parthenogenetic generations] // Zool. Zhurn. Vol.93. P.426-442 [in Russian with English summary].

Galaktionov K.V., Podvyaznaya I.M., Nikolaev K.E., Levakin I.A. 2015. Self-sustaining infrapopulation or colony? Redial clonal groups of Himasthla elongata (Trematoda: Echinostomatidae) in Littorina littorea (Gastropoda: Littorinidae) do not support the concept of eusocial colonies in trematodes // Folia Parasitol. Vol.62. No. 067 (Open access, http://folia.paru.cas.cz/ artkey/fol-201501-0067_Self-sustaining infrapopulation_or_colony_Redial_clonal_groups _of_Himasthla_elongata_Mehlis_1831_Trematoda. php; doi: $10.1 \overline{4} 411 / \mathrm{fp} .2015 .067)$

Galaktionov K.V., Irwin S.W.B., Prokofiev V.V., Saville D.H., Nikolaev K.E., Levakin I.A. 2006. Trematode transmission in coastal communities - temperature dependence and climate change perspectives // 11th 
International Congress of Parasitology (ICOPA XI). Medimond International Proceedings. P.85-90.

Gerasev P.I., Dobrovolskij A.A. 1977. [Development of the hermaphroditic generation of Astiotrema trituri (Trematoda, Plagiorchiidae)]// Parasitol. Sbornik Zool. Inst. RAN. Vol.27. P.89-111 [in Russian with English summary].

Ginetsinskaya T.A. 1968. [Trematodes, their life cycles, biology and evolution.] Leningrad: Nauka. USSR. 411 p. [In Russian] (Translated in 1988 by Amerind Publ. Co. Pvt. Ltd., New Delhi.)

Hughes R.N., Answer P. 1982. Growth, spawning and trematode infestation of Littorina littorea (L.) from an exposed shore in North Wales // J. Moll. Stud. Vol.48. P.321-330.

Isakova N.P. 2011. [The nature of the germinal mass (gonad) in the trematode parthenitae (Trematoda)] // Parazitologiya. Vol.45. No.6. P.438-448 [in Russian with English summary].

Kendall S.B. 1965. Relationships between species of Fasciola and their molluscan hosts // Adv. Parasitol. Vol.3. P.59-98.

Kofiadi A.Kh. 1995. [Structure of germinal masses and some problems of the dynamics of daughter sporocysts' development in Hemiuridae gen. sp.] // Parazitologiya. Vol.29. P.404-416 [in Russian with English summary].

Køie M. 1975. On the morphology and life-history of Opechona bacillaris (Molin,1859) Loos, 1907 (Trematoda, Lepocreadiidae // Ophelia. Vol.13. P.63-86.

Korniychuk Yu.M. 2008. [Parthenogenetic generations of Helicometra fasciata Rud., 1819 (Trematoda: Opecoelidae) in the Black Sea molluscs Gibbula adriati$c a$ ] // Parazitologiya. Vol.42. No.1. P.41-52 [in Russian with English summary].

Kube S., Kube J., Bick A. 2002. Component community of larval trematodes in the mudsnail Hydrobia ventrosa: temporal variation in prevalence in relation to host life history // J. Parasitol. Vol.88. P.730-737.

Lauckner G. 1980. Diseases of Mollusca: Gastropoda // O. Kinne (ed.). Diseases of marine animals. Vol. 1. Chichester et al.: Wiley \& Sons. P.311-424.

Lemly A.D., Esch G.W. 1984. Population biology of the trematode Uvulifer ambloplitis (Hughes, 1927) in the snail intermediate host, Helisoma trivolvis // J. Parasitol. Vol.70. P.461-465.

Levakin I.A. 2005. [The influence of infection with trematodes Bunocotylee progenetica (Hemiuridae) and Cryptocotyle lingua (Heterophyidae) onto mortality of littoral mollusks Hydrobia ulvae (Gastropoda: Prosobranchia) after freezing] // Parazitologiya. Vol.39. No.5. P.407-413 [in Russian with English summary].

Levakin I.A. 2008. [Transmission of the monoxenous life cycle of Bunocotyle progenetica (Trematoda: Hemiuroidea, Bunocotylinae) under conditions of the White Sea intertidal]. PhD Thesis [Kand. Biol. Nauk. Dissertation]. St. Petersburg: Zool. Inst. RAN. 171 p. [In Russian]

Machkevskiy V.K. 1982. The peculiarities of development and biology of the parthenitae of Proctoeces maculatus (Trematoda) in the Black Sea blue mussels // Zool. Zhurn. Vol.61. No.11. P.63-86 [in Russian with English summary].

Marcogliese D.J. 2001. Implications of climate change for parasitism of animals in the aquatic environment // Can. J. Zool. Vol.79. P.1331-1352.

Mukhamedov G.K. 1979. [Seasonal dynamics of the development and reproduction of the parthenogenetic generations of Xiphidiocercaria sp. VII Odening, 1962 (Trematoda: Plagiorchiidae) in the mollusc Coretus corneus] // Parazitologiya. Vol.12. P.444-448 [in Russian with English summary].

Mukhamedov G.K.1981. [Patterns in development and reproduction of parthenogenetic generations of some trematodes]. Ph.D. Thesis. [Kand. Biol. Nauk. Dissertation]. Leningrad: Leningrad State University. 248 p. [In Russian]

Nikolaev K.E. 2012. [Peculiarities of transmission of the life cycles of trematodes of the families Echinostomatidae and Renicolidae in intertidal ecosystems of the White Sea. PhD Thesis [Kand. Biol. Nauk. Dissertation]. St. Petersburg: Zool. Inst. RAN. 300 p. [In Russian]

Peterson N. 2007. Seasonal prevalence of Ribeiroia ondatrae in one population of Planorbella trivolvis (=Helisoma trivolvis), including notes on the larval trematode component community // Comp. Parasitol. Vol.74. No.2. P.312-318.

Podvyaznaya I.M. 2007. An ultrastructural study of reproduction in the sporocysts of Prosorhynchoides gracilescens (Digenea: Bucephalidae) // Parasitol. Res. Vol.101. P.35-42.

Podvyaznaya I.M., Galaktionov K.V. 2014. Trematode reproduction in the molluscan host: an ultrastructural study of the germinal mass in the rediae of Himasthla elongata (Mehlis, 1831) (Digenea: Echinostomatidae) // Parasitol. Res. Vol.113. P.1215-1224.

Podvyaznaya I.M., Galaktionov K.V. 2018. Reproduction of trematodes in the molluscan host: an ultrastructural study of the germinal mass and brood cavity in daughter rediae of Tristriata anatis Belopolskaia, 1953 (Digenea: Notocotylidae) // Parasitol. Res. Vol.117. P.2643-2652.

Podvyaznaya I.M., Petrov A.A., Galaktionov K.V. 2019. The fine structure of the germinal mass, brood cavity and birth canal of the rediae of the monoxenous hemiuroid digenean Bunocotyle progenetica Chabaud \& Buttner, 1959 // J. Helminthol. https://doi.org/ 10.1017/S0022149X19000816

Prinz K., Kelly T.C., O'Riordan R.M., Culloty S.C. 2011. Factors influencing cercarial emergence and settlement in the digenean trematode Parorchis acanthus (Philophthalmidae) // J. Mar. Biol. Ass. UK. Vol.91. P.1673-1679.

Prokofiev V.V. 2006. Strategies of the animal host infection with trematode cercariae: an attempt of analysis in marine coastal and lake ecosystems of Northwestern Russia. Dr. Biol. Sci. Thesis [Doct. Biol. Nauk. Dissertation]. St. Petersburg: Zool. Inst. RAN. 545 p. [In Russian] 
Robson E.M., Williams I.C. 1970. Relationships of some species of Digenea with the marine prosobranch Littorina littorea (L.). I. The occurence of larval Digenea in L. littorea on the North Yorkshire coast // J. Helminthol. Vol.44. P.153-168.

Rusanov N.I., Galaktionov K.V. 1984. [Seasonal dynamics of development and reproduction of the parthenitae of Podocotyle atomon (Rudolphi, 1802) (Trematoda: Opecoelidae) in the littoral molluscs of the Barents Sea] // Yu.I. Poljansky (ed.). Ekologo-Parazitol. Issled. Sever. Morei. Apatity: USSR. Kola Nauchn. Tsentr AN SSSR. P.41-51 [in Russian with English summary].

Schmidt K.A., Fried B. 1997. Prevalence of larval trematodes in Helisoma trivolvis (Gastropoda) from a farm pond in Northampton County, Pennsylvania with special emphasis on Echinostoma trivolvis (Trematoda) cercariae // J. Helminthol. Soc. Wash. Vol.64. No.1. P.157-159.
Sendersky I.V., Kurbatov I.V., Dobrovolskij A.A. 2002. [Parthenogenetic generations of Sanguinicola armata (Trematoda: Sanguinicolidae)]// Parazitologiya. Vol.36. No.6. P.469-477 [in Russian with English summary]. Smyth J.D., Halton D.W. 1983. The physiology of trematodes. 2nd edition. Cambridge, U.K.: Cambridge University Press. 446 p.

Taskinen J., Valtonen E.T., Mäkelä T. 1994. Quantity of sporocysts and seasonality of two Rhipidocotyle species (Digenea: Bucephalidae) in Anodonta piscinalis (Mollusca: Bivalvia) // Int. J. Parasitol. Vol.24. No.6. P.877-886.

Thieltges D.W., Rick J. 2006. Effect of temperature on emergence, survival and infectivity of cercariae of the marine trematode Renicola roscovita (Digenea: Renicolidae) // Dis. Aquat. Organ. Vol.73. P. 63-68.

Werding B. 1969. Morphologie, Entwicklung und Ökologie digener Trematoden-Larven der Strandschnecke Littorina littorea // Mar. Biol. Vol.3. P.306-333.

Responsible editor: A.Yu. Sinev 